\title{
Alpha Toxin from Clostridium perfringens Induces Proinflammatory Changes in Endothelial Cells
}

\author{
Michaeline Bunting, ${ }^{\star \neq \|}$ Diane E. Lorant, ${ }^{\ddagger \star \star}$ Amy E. Bryant, ${ }^{\ddagger \ddagger}$ Guy A. Zimmerman, ${ }^{\ddagger \S}$ Thomas M. Mclntyre, ${ }^{\ddagger \uparrow}$ Dennis L. Stevens, ${ }^{\ddagger \ddagger}$ \\ and Stephen M. Prescott ${ }^{\star \star \$} \|$ \\ *The Eccles Program in Human Molecular Biology and Genetics, the ${ }^{\ddagger}$ Nora Eccles Harrison Cardiovascular Research and Training \\ Institute, the Department of ${ }^{\S}$ Internal Medicine, "the Department of Biochemistry, "the Department of Pathology, and **the Department of \\ Pediatrics, University of Utah, Salt Lake City, Utah 84112; and Department of Internal Medicine, University of Washington School of \\ Medicine, and Boise Veterans Medical Center, Boise, Idaho 83702
}

\begin{abstract}
Alpha toxin from Clostridium perfringens type A, a phospholipase $\mathrm{C}$, has been implicated in many of the localized and systemic features of gas gangrene. We demonstrated that human endothelial cells synthesize two vasoactive lipids, platelet-activating factor (PAF) and prostacyclin, in response to alpha toxin treatment. The stimulated synthesis of PAF required the enzymatic activity of the toxin and subsequent protein kinase $C$ activation. Alpha toxin-treated endothelial cells accumulated the products of the phospholipase $\mathrm{C}$ reaction, diacylglycerol and ceramide, and exhibited a decrease in the enzymatic precursors phosphatidylcholine and sphingomyelin. Furthermore, the temporal accumulation of PAF depended on the concentration of the toxin in the overlying medium and was blocked in the presence of a neutralizing antibody. The cultured endothelial cells also exhibited enhanced neutrophil adhesion in response to alpha toxin which was mediated through the PAF receptor and P-selectin. P-selectin expression by endothelial cells and extravascular neutrophil accumulation were also observed in tissue sections from alpha toxin-injected Sprague-Dawley rats. These endothelial cell-mediated processes are important in maintaining vascular homeostasis and, when activated in a dysregulated manner by $C$. perfringens alpha toxin, may contribute to localized and systemic manifestations of gas gangrene including enhanced vascular permeability, localized neutrophil accumulation, and myocardial dysfunction. (J. Clin. Invest. 1997. 100:565-574.) Key words: phospholipase $\mathrm{C} \cdot$ platelet-activating factor - endothelium $\bullet$ epoprostenol $\bullet$ cell adhesion
\end{abstract}

\section{Introduction}

Gas gangrene is a dramatic, life-threatening syndrome caused by Clostridium perfringens type A. The clinical features include localized pain and swelling, myonecrosis, tachycardia, and, when left untreated, shock and death (1). The basis for the profound systemic effects is not known, but one crucial ob-

Address correspondence to Dr. Stephen M. Prescott, Eccles Institute of Human Genetics, Building 533, University of Utah, Salt Lake City, UT 84112. Phone: 801-585-3401; FAX: 801-585-6345.

Received for publication 9 December 1996 and accepted in revised form 22 April 1997.

J. Clin. Invest.

(c) The American Society for Clinical Investigation, Inc. 0021-9738/97/08/0565/10 \$2.00

Volume 100, Number 3, August 1997, 565-574

http://www.jci.org servation is that they can occur without septicemia. Thus, many of the effects must be due to generation of inflammatory mediators at the site of infection, which then exert their actions at remote sites. In many types of bacterial infections these actions are caused by bacterial toxins which reach the circulation (toxemia). An additional feature may be the activation of inflammatory cells, either in the circulation or at the site of infection. For example, upon activation leukocytes synthesize platelet-activating factor $(\mathrm{PAF})^{1}$ and secrete potent inflammatory mediators such as cytokines, eicosanoids, as well as toxic oxygen radicals and proteases, all of which can contribute to physiological actions such as those observed in patients with gas gangrene. A characteristic, but unexplained, feature of infections with this organism is the massive accumulation of neutrophilic PMNs at the margins of the infected area (2). The systemic effects of $C$. perfringens infection may then result from actions of one or more circulating toxins, the synthesis and release of inflammatory mediators at the site of infection, or both. The pathogenicity of $C$. perfringens has been correlated with the secreted alpha toxin (3-5), a phospholipase $\mathrm{C}(6,7)$, but the mechanism by which it elicits pathological responses has been elusive. This has resulted, in part, from the limited availability of highly purified toxin, which is needed to distinguish the effects due to alpha toxin from those caused by other exotoxins of $C$. perfringens. Recently, several groups have reported the isolation of the gene for alpha toxin from $C$. perfringens (8-11). We used alpha toxin purified from an $E s$ cherichia coli overexpression system (8) to investigate its effects on endothelial cells. Our rationale was that we have previously shown that endothelial cells are active participants in signaling the adhesion and activation of neutrophils. For example, we found that stimulation of endothelial cells with thrombin, histamine, bradykinin, or peptidoleukotrienes causes them to become adhesive for PMNs, even though none of these agonists affect PMNs directly (12-14). The molecular mechanisms for this response include the transfer of a glycoprotein, P-selectin (previously known as GMP-140 or PADGEM), from Weibel-Palade bodies to the endothelial cell surface where it serves to tether PMNs without activating them (1416). Simultaneously, stimulated endothelial cells synthesize PAF, a novel proinflammatory phospholipid, which activates the adherent PMNs and thereby strengthens binding by recruitment of the leukocyte $\beta_{2}$-integrins $(15,17)$. PAF also primes the leukocytes for subsequent secretion of oxygen radicals and proteases (16).

1. Abbreviations used in this paper: DAG, diacylglycerol; HBSS/A, HBSS containing $1 \mathrm{mg} / \mathrm{ml}$ fatty acid-free BSA; HUVEC, human umbilical vein endothelial cells; PAF, 1-O-alkyl-2-acyl phosphatidylcholine, also known as platelet-activating factor; $\mathrm{PKC}$, protein kinase $\mathrm{C}$. 
We reasoned that endothelial cells may be exposed to bacterial exotoxins during $C$. perfringens infections which could cause dysregulated expression of these proinflammatory signals by endothelial cells. This would result in a marked recruitment of PMNs and their inappropriate activation. Thus, in an infection with $C$. perfringens some of the local and systemic effects may be due to dysregulated activation of endothelial cells by an exotoxin. We report here that we observed this set of responses when cultured endothelial cells were exposed to recombinant alpha toxin from $C$. perfringens.

\section{Methods}

Materials. $\left[{ }^{3} \mathrm{H}\right]$ Acetate $(3.4 \mathrm{Ci} / \mathrm{mmol})$ and $\left[\gamma^{-32} \mathrm{P}\right] \mathrm{ATP}(10 \mathrm{Ci} / \mathrm{mmol})$ were purchased from NEN-DuPont (Wilmington, DE). $\left[{ }^{3} \mathrm{H}\right]$ Arachidonic acid $(200 \mathrm{Ci} / \mathrm{mmol})$ was obtained from American Radiolabeled Chemicals (St. Louis, MO). Phospholipids were obtained from Avanti Polar Lipids (Alabaster, AL). Phospholipases $\mathrm{A}_{1}$ (Rhizopus arrhizus), phospholipase $\mathrm{A}_{2}$ (bee venom), fatty acid-free BSA, butylhydroxytoluene, deoxycholate, and A23187 were purchased from Sigma Chemical Co. (St. Louis, MO). PAF acetylhydrolase was a gift from Dr. Diana Stafforini at the University of Utah (Salt Lake City, UT) and was prepared as described (18). Purified alpha toxin from C. perfringens was a generous gift from Dr. J.Y. Tso at Protein Design Labs Inc. (Mountain View, CA) and was prepared as previously described (8). An affinity-purified $\mathrm{mAb}$ to alpha toxin, $1 \mathrm{C} 6 \mathrm{~F} 4$, with neutralizing activity was also a gift from Dr. J.Y. Tso (19). The PB1.3 IgG1 mAb was obtained from Cytel Corp. (San Diego, CA). Culture medium M199 and HBSS were obtained from Whittaker M.A. Bioproducts, Inc. (Walkersville, MD). Sphingosine, staurosporine, and sangivamycin were obtained from Sigma Chemical Co., Calbiochem Corp. (San Diego, CA), and the Natural Products Branch, Division of Cancer Treatment, National Cancer Institute, respectively. All solvents were HPLC grade, and were obtained from J.T. Baker. E. coli diacylglycerol (DAG) kinase was purchased from Lipidex (Westfield, NJ) and is now available from Amersham Corp. (Arlington Heights, IL).

Alpha toxin. The specific activity of the alpha toxin was determined as previously described (20). Briefly, $1 \mathrm{U}$ of activity is defined as that which hydrolyzes $1 \mathrm{nmol}$ of $p$-nitrophenylphosphorylcholine in $30 \mathrm{~min}$ at $37^{\circ} \mathrm{C}$. The purity of the alpha toxin preparation which was used in this study was previously demonstrated (21).

Cell culture. Primary confluent endothelial cells were cultured in p35 dishes from the veins of human umbilical cords as described previously (22).

Synthesis of 1-O-radyl-2-[3] Hacetyl-sn-glycero-3-phosphocholine ${ }^{2}$ $(P A F$ and acylPAF) by endothelial cells. The cellular accumulation of PAF and acylPAF was determined essentially as previously described (23). Briefly, confluent human endothelial cells were incubated with $25 \mu \mathrm{Ci} / \mathrm{ml}\left[{ }^{3} \mathrm{H}\right]$ acetate in HBSS containing fatty acid-free bovine serum albumin at $1 \mathrm{mg} / \mathrm{ml}$ (HBSS/A) and $0.1 \mathrm{mM} \mathrm{ZnCl}_{2}$, with the specified concentration of alpha toxin, for the indicated period of time at $37^{\circ} \mathrm{C}$. The reactions were stopped by the addition of acidified $\mathrm{MeOH}$ and the phospholipids were extracted and separated by TLC $\mathrm{CHCl}_{3} / \mathrm{MeOH} / \mathrm{HOAc} / \mathrm{H}_{2} \mathrm{O}$ (5:2.5:0.8:0.4). The amount of radiolabel incorporation into PAF was determined by liquid scintillation spectrometry. For experiments in which we calculated the amount of radiolabeled PAF released by the endothelial cell monolayer, the medium from stimulated endothelial cells was centrifuged for $10 \mathrm{~min}$ $(350 \mathrm{~g})$ and the fluid phase was further analyzed for radiolabeled PAF as described above. The quantity of radiolabeled PAF in the medium was divided by the total amount of radiolabeled PAF synthesized by the monolayer to determine the percentage of PAF released by the endothelial cells.

2. The term radyl is used to describe compounds with either an ether or ester linkage between a fatty acid and the glycerol backbone.
We performed a variety of experiments to characterize the product labeled with $\left[{ }^{3} \mathrm{H}\right]$ acetate, and each supported the conclusion that the product was 1-radyl-2-[ $\left.{ }^{3} \mathrm{H}\right]$ acetyl-sn-glycero-3-phosphocholine. Confluent human umbilical vein endothelial cells (HUVECs) were treated with $0.2 \mathrm{U} / \mathrm{ml}$ alpha toxin for $40 \mathrm{~min}$, extracted, and developed on TLC as described above. The labeled product migrated in the same fraction as authentic PAF standards on TLC. TLC sections corresponding to the radiolabeled lipid species were scraped from the plate, sonicated for $2 \mathrm{~min}(60 \mathrm{~Hz})$ in the presence of $\mathrm{MeOH} / \mathrm{CHCl}_{3} /$ $\mathrm{H}_{2} \mathrm{O}$ (25:12.5:10), and extracted by the method of Bligh and Dyer (24). Portions of the lipid extract, in addition to authentic standards, were dried under $\mathrm{N}_{2}$ and subjected to HPLC analysis or selective enzymatic hydrolysis with PAF acetylhydrolase (18), phospholipase $\mathrm{A}_{1}$ (23), or phospholipase $A_{2}$ under conditions in which the substrate was limiting. For HPLC analysis the lipid fraction was dissolved in 1:1 hexane/isopropanol and an aliquot was loaded onto a Beckman HPLC equipped with a column $(4.5 \mathrm{~mm} \times 25 \mathrm{~cm})$ (Ultrasphere $\mathrm{Si}-05$; Beckman Instruments, Fullerton, CA) and a Berthold in-line radioactivity monitor. The radiolabeled product, as well as synthetic PAF standards, eluted as a single peak of radioactivity with a retention time of $26 \mathrm{~min}$ in the following conditions: solvent $\mathrm{A}$ (1:1 hexane/isopropanol), solvent $\mathrm{B}\left(\mathrm{H}_{2} \mathrm{O}\right)$, flow $1.0 \mathrm{ml} / \mathrm{min}$, gradient $96 \% \mathrm{~A}(0-5 \mathrm{~min})$ to $92 \% \mathrm{~A}(5-30 \mathrm{~min})$. For $\mathrm{PLA}_{2}$ assays, the radiolabeled lipid was incubated for $1 \mathrm{~h}$ at $37^{\circ} \mathrm{C}$ in $100 \mathrm{mM}$ Tris- $\mathrm{HCl}, \mathrm{pH} 7.5,1.3 \mathrm{mM}$ deoxycholate, $6.7 \mathrm{mM} \mathrm{CaCl}_{2}$, and $267 \mu \mathrm{M}$ butylhydroxytoluene with $25 \mathrm{U}$ $\mathrm{PLA}_{2}$ after which an additional $25 \mathrm{U}$ was added and the reaction continued for an additional hour. Each reaction was extracted by the method of Bligh and Dyer (24) and the lipid products were separated by TLC as described above to characterize the remaining radiolabeled lipid products.

In each of the experiments using the alpha toxin-specific mAb a fivefold excess of this neutralizing antibody was used. In the experiments shown in Fig. $3 A$ the stimulation medium was preincubated with the corresponding antibodies or buffer alone for $1 \mathrm{~h}$ at $37^{\circ} \mathrm{C}$ before it was added to the cell monolayers. In the experiments shown in Fig. $3 B$, the neutralizing antibody was added at various times to the stimulation medium overlying the endothelial cells.

To examine the role of protein kinase $\mathrm{C}$ (PKC) in PAF synthesis, endothelial cells were preincubated in HBSS/A containing varying concentrations of staurosporine $(0-500 \mathrm{nM})$, sphingosine $(0-100 \mu \mathrm{M})$, or sangivamycin $(0-40 \mu \mathrm{M})$ for 15,15 , or $5 \mathrm{~min}$, respectively. Cells were then stimulated with $0.2 \mathrm{U} / \mathrm{ml}$ alpha toxin in HBSS/A containing $0.1 \mathrm{mM} \mathrm{ZnCl}{ }_{2}$ for $40 \mathrm{~min}$ at $37^{\circ} \mathrm{C}$ and assayed for PAF as described above.

Studies of arachidonic acid turnover and prostaglandin production. Endothelial cells were labeled with $0.25 \mu \mathrm{Ci} / \mathrm{ml}\left[{ }^{3} \mathrm{H}\right]$ arachidonic acid in M199, for $3 \mathrm{~h}$ before exposure to alpha toxin. The cells were washed twice with HBSS and stimulated for various times with either $0.2 \mathrm{U} / \mathrm{ml}$ alpha toxin in HBSS/A containing $0.1 \mathrm{mM} \mathrm{ZnCl}_{2}$ buffer alone (negative control), or with $10 \mu \mathrm{M} \mathrm{A} 23187$ (positive control) for $15 \mathrm{~min}$. Immediately after the stimulation period, the cell supernatant was transferred to a microfuge tube and centrifuged for $15 \mathrm{~min}$ $(16,000 \mathrm{~g})$ to remove cell debris. The resulting supernatant was transferred to a scintillation vial and the radioactivity was quantified by scintillation spectrometry. Additionally, the supernatants from unlabeled endothelial cells treated in the same manner were collected and assayed for 6-keto-PGF ${ }_{1 \alpha}$, the stable breakdown product of prostaglandin $\mathrm{I}_{2}\left(\mathrm{PGI}_{2}\right)$, by RIA (23).

Quantification of diacylglycerol, alkylacylglycerol, and ceramide. Alpha toxin-stimulated endothelial cells were collected after the addition of $1.0 \mathrm{ml} \mathrm{MeOH}$ and the lipids were isolated by a Bligh and Dyer extraction (24). The lower phase of each extract was dried under $\mathrm{N}_{2}$ and treated with E. coli DAG kinase in the presence of $\left[{ }^{32} \mathrm{P}\right]$ ATP as previously described (25). The resulting $\left[{ }^{32} \mathrm{P}\right]$ phosphatidic acid species and ceramide $\left[{ }^{32} \mathrm{P}\right]$ phosphate were separated by silica gel TLC in $\mathrm{CHCl}_{3} / \mathrm{MeOH} / \mathrm{HOAc}$ (325:75:25) and quantified by liquid scintillation spectrometry. The alkylacylglycerol fraction was determined by incubating a fraction of the phosphorylated product in 
a 200- $\mu$ l volume of $0.3 \mathrm{~N} \mathrm{NaOH}, 90 \%$ methanol, for $15 \mathrm{~min}$ at $90^{\circ} \mathrm{C}$. The resulting 1-O-alkyl-2-hydroxy phosphatidic acid was extracted into the organic phase of an acidic Bligh and Dyer (24), submitted to thin layer chromatography in $\mathrm{CHCl}_{3} / \mathrm{MeOH} / \mathrm{HOAc} / \mathrm{H}_{2} 0$ (10:3:3.5: 0.3 ), and quantified by liquid scintillation counting. Authentic DAG and 1-O-alkyl-2-acyl glycerol were carried through to determine $R_{\mathrm{f}}$ and recovery.

Neutrophil adhesion to endothelial cells. PMNs were isolated from human venous blood and labeled with ${ }^{111}$ In as described (12). Neutrophil adhesion to endothelial cell monolayers was performed and quantitated as described (12). In experiments where we examined the effect of the PAF receptor antagonist, L659,989, on neutrophil adhesion, the neutrophils were pretreated with $100 \mu \mathrm{M} \mathrm{L659,989}$ for $5 \mathrm{~min}$ before addition to the endothelial cell monolayers (17). In experiments where the P-selectin-mediated adhesion was blocked by the $\mathrm{mAb} \mathrm{G1}$, the endothelial cells were incubated for 30 min with $25 \mu \mathrm{g} /$ $\mathrm{ml} \mathrm{mAb} \mathrm{G1} \mathrm{and} \mathrm{the} \mathrm{neutrophil} \mathrm{suspension} \mathrm{contained} \mathrm{mAb} \mathrm{G1} \mathrm{(10}$ $\mu \mathrm{g} / \mathrm{ml}$ ) during the 10-min adhesion assay (15). All monolayers were washed twice with $1 \mathrm{ml} \mathrm{HBSS}$ after stimulation and before the neutrophil adhesion assay.

Immunohistochemical staining and histology of alpha toxininjected rats. Sprague-Dawley rats (100-150 g) were injected intermuscularly with $100 \mu \mathrm{l}$ PBS or $100 \mu \mathrm{l}$ PBS containing $1 \mathrm{U}$ of alpha toxin. After varying times, the rats were sedated with intraperitoneal chloral hydrate $(0.4 \mathrm{~g} / \mathrm{kg}$ body $\mathrm{wt})$ and killed by cervical dislocation. The muscle at the injection site was excised and fixed in ice cold $4 \%$ paraformaldehyde for $1 \mathrm{~h}$. The tissue was then dehydrated in a graded series of ethanol at $4^{\circ} \mathrm{C}$ and embedded (Immunobed; Polysciences Inc., Warrington, PA) at $4^{\circ} \mathrm{C}$ for $24 \mathrm{~h}$. 4-mm-thick sections were cut using glass knives and transferred to glass microscopy slides.

Immunohistochemical detection of P-selectin was performed using the avidin-biotin immunoperoxidase technique (Vectastain $\mathrm{ABC}$ Reagent; Vector Laboratories Inc., Burlingame, CA). The sections were incubated overnight at room temperature with PB1.3, a P-selectin-specific mAb (26), at a dilution of 1:50. The secondary antibody was applied as per the manufacturer's instructions provided with the Vectastain kit. The sections were counter stained with hematoxylin and permanently mounted with coverslips. The slides were examined and photographed with Normarski interference contrast optics using a light microscope (Axioplan; Carl Zeiss, Inc., Thornwood, NY). In control experiments where the primary antibody to P-selectin was omitted, no immunoperoxidase staining of the tissue sections was observed.

\section{Results}

Alpha toxin stimulates endothelial cells to synthesize pro-inflammatory compounds: PAF and prostacyclin. The addition of alpha toxin to confluent monolayers of human endothelial cells stimulated the synthesis of PAF (Fig. 1). In the experiment shown we added $0.2 \mathrm{U}$ of toxin $/ \mathrm{ml}$ of incubation medium, and found that peak accumulation was at $40 \mathrm{~min}$. Buffer-treated endothelial cells did not synthesize PAF when incubated in parallel. We further examined the toxicity of the alpha toxin to endothelial cells at this concentration by Trypan blue exclusion and lactate dehydrogenase release. After incubation with alpha toxin for $120 \mathrm{~min}$ we did not detect lactate dehydrogenase activity in the media $(n=3)$ and observed that $9.3 \pm 1.5 \%$ of the cells stained positive with Trypan blue $(n=3)$. These results demonstrate that most endothelial cells retain cellular integrity under these conditions.

We have shown previously that virtually all of the PAF synthesized by endothelial cells in response to histamine, bradykinin, and ATP remains associated with the cells, and a substantial fraction is on the surface (23). We found, however, that $5.1 \pm 1.1 \%$ and $22.2 \pm 0.3 \%$ of the PAF synthesized by endothe-

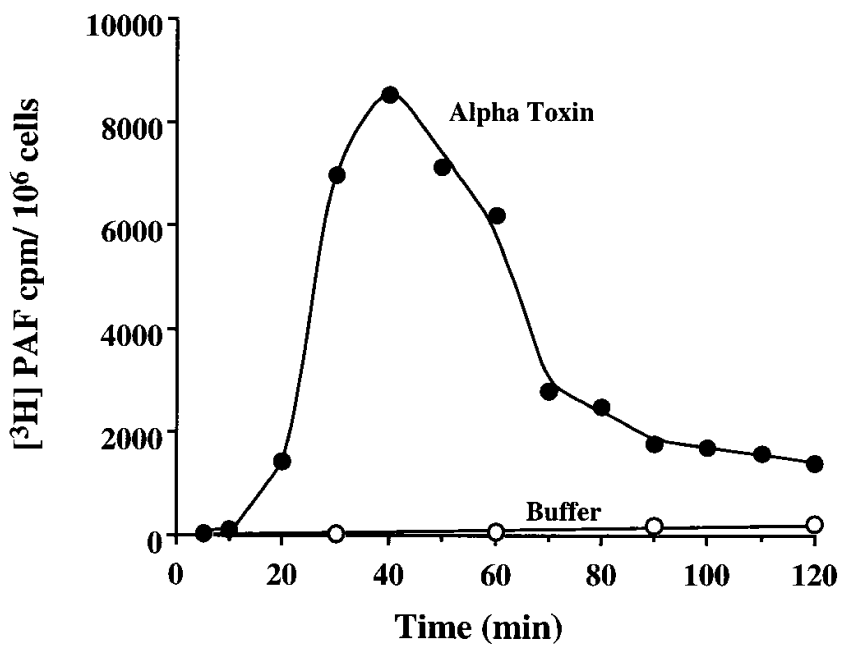

Figure 1. Alpha toxin from C. perfringens stimulates PAF synthesis by endothelial cells. HUVEC were incubated with HBSS, $1 \mathrm{mg} / \mathrm{ml}$ BSA, and $1 \mathrm{mM} \mathrm{ZnCl} 2\left(\mathrm{HBSS} / \mathrm{A} / \mathrm{Zn}^{2+}\right.$ ) containing [ $\left.{ }^{3} \mathrm{H}\right]$ acetate (open circles) or $\mathrm{HBSS} / \mathrm{A} / \mathrm{Zn}^{2+}$ containing $\left[{ }^{3} \mathrm{H}\right]$ acetate and $0.2 \mathrm{U} / \mathrm{ml}$ alpha toxin (closed circles). At the time points shown, the cellular lipids were extracted and $\left.{ }^{3} \mathrm{H}\right] \mathrm{PAF}$ was isolated by TLC and then quantified by liquid scintillation spectroscopy. The results shown are from one experiment but the general pattern of PAF accumulation is typical of that observed in five additional experiments conducted in a similar manner.

lial cells was released into the supernatant at 30 and $60 \mathrm{~min}$, respectively, after the addition of alpha toxin $(0.2-2 \mathrm{U} / \mathrm{ml})$. One possible explanation for the apparent release of PAF into the medium was that the endothelial cells stimulated with alpha toxin detached from the monolayers. This explanation was excluded by several approaches. First, the medium samples were centrifuged before analysis to remove any endothelial cells in the fluid phase. Second, we observed that $58.9 \pm 5.7 \%$ of the PAF released into the medium passed through a $0.2-\mu \mathrm{m}$ filter. The mechanism by which this lipid mediator is released into the fluid phase remains to be established but may be a reflection of membrane blebbing, as previously observed with oxidant-damaged endothelium (27), or the release of membrane fragments generated by the phospholipase $\mathrm{C}$ activity of alpha toxin.

To demonstrate that the metabolic labeling with $\left[{ }^{3} \mathrm{H}\right]$ acetate specifically measured the production of PAF, we performed several experiments to characterize the labeled product. The labeled species which comigrated with PAF standards on TLC also eluted in the same fraction as PAF standards on HPLC using a solvent system that separates PAF from similar phospholipid species $(28,29)$. Furthermore, we observed that $>95 \%$ of the $\left[{ }^{3} \mathrm{H}\right]$ acetate label was released from PAF in the presence of $\mathrm{PLA}_{2}$ or PAF acetylhydrolase. However, only $6 \%$ of the labeled product was lost when exposed to $\mathrm{PLA}_{1}$ under conditions in which a similar compound containing a 1-acyl linkage was degraded by $81 \%$. These results confirm that the radiolabeled product we observed was predominantly authentic PAF.

Endothelial cells respond in a variety of other ways to activation with agonists. One of these responses is the release of arachidonic acid and its conversion to $\mathrm{PGI}_{2}$ (23). This may 


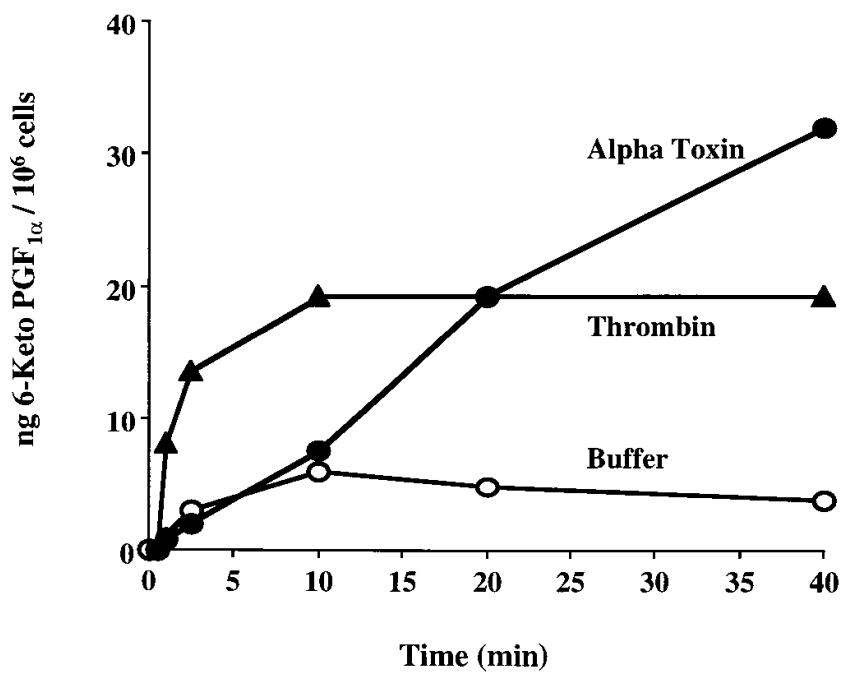

Figure 2. Alpha toxin stimulates the synthesis and release of prostacyclin by endothelial cells with different kinetics than thrombin. Human endothelial cells were stimulated with $0.2 \mathrm{U} / \mathrm{ml}$ alpha toxin (filled circles), $2.0 \mathrm{U} / \mathrm{ml}$ thrombin (filled triangles), or $\mathrm{HBSS} / \mathrm{A} / \mathrm{Zn}^{2+}$ only (open circles) for the times shown. The stimulation buffer was collected and assayed for 6-keto-PGF ${ }_{1 \alpha}$, the stable breakdown product of $\mathrm{PGI}_{2}$, by RIA. The results depicted are from a single experiment but are typical of three experiments which were conducted similarly.

have particular relevance for shock since this latter compound is a potent vasodilator (30). We determined if exposure of endothelial cells to alpha toxin also resulted in the release of arachidonic acid and its conversion to $\mathrm{PGI}_{2}$. We labeled endothelial cells with $\left[{ }^{3} \mathrm{H}\right]$ arachidonate, exposed them to alpha toxin $(0.2 \mathrm{U} / \mathrm{ml}$ for $30 \mathrm{~min})$, and measured the release of the label. Monolayers treated with alpha toxin released $19.3 \%$ of the radiolabeled arachidonate, whereas buffer-treated cells released $5.6 \%$. In a parallel incubation, cells exposed to the calcium ionophore A23187 $(10 \mu \mathrm{M})$ for $15 \mathrm{~min}$ resulted in $8.6 \%$ release. Thus, there was a dramatic stimulation of arachidonate release from membrane phospholipids in response to the toxin. We next examined supernatants from toxin-treated cells for the presence of 6-keto-PGF ${ }_{1 \alpha}$, the stable breakdown product of $\mathrm{PGI}_{2}$, which is the major product derived from arachidonic acid in these cells (31). We found a time-dependent increase, indicating that after its release the arachidonic acid was converted into this potent vasodilator (Fig. 2). Additionally, we observed that the pattern and magnitude of synthesis and release of $\mathrm{PGI}_{2}$ from endothelial cells in response to alpha toxin differed from that observed in response to the physiological agonist, thrombin. Whereas the $\mathrm{PGI}_{2}$ release by the thrombin-treated cells was maximal at $10 \mathrm{~min}$ we observed increasing levels of $\mathrm{PGI}_{2}$ as late as 40 min after the addition of alpha toxin. Furthermore, after $40 \mathrm{~min}$ of stimulation, the level of $\mathrm{PGI}_{2}$ in the medium of alpha toxin-treated cells exceeded that of thrombin- or buffer-treated cells.

$P A F$ synthesis depends upon the concentration of active alpha toxin and PKC activation. We observed PAF synthesis and accumulation at concentrations as low as $0.05 \mathrm{U} / \mathrm{ml}$ with a maximal response at $0.6 \mathrm{U} / \mathrm{ml}$ of toxin. Interestingly, the time of peak accumulation depended on the concentration of toxin used. For example, with $0.6 \mathrm{U} / \mathrm{ml}$ of toxin the peak accumulation occurred at $\sim 20 \mathrm{~min}$, while with $0.05 \mathrm{U}$ the accumulation was still increasing as late as $1 \mathrm{~h}$ after the addition of toxin. This suggested that the effect of the toxin was a consequence of its enzymatic activity. To examine this issue, and to demonstrate that the cellular response was due to the toxin and not a contaminant of the preparation, we included a specific, neutralizing antibody to the toxin. As shown in Fig. 3, when the $\mathrm{mAb}$ was included throughout the incubation, no PAF synthesis was detected. Furthermore, if immunoglobulin from a nonimmune rabbit was added to the endothelial cells along with the alpha toxin, the subsequent PAF synthesis was not dimin-
A

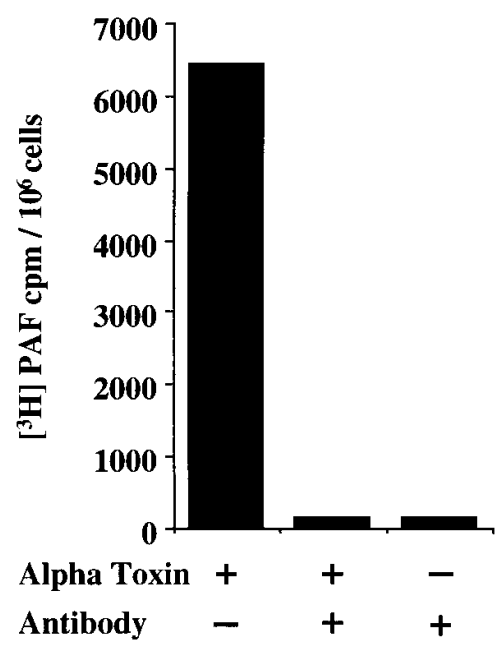

$\mathbf{B}$

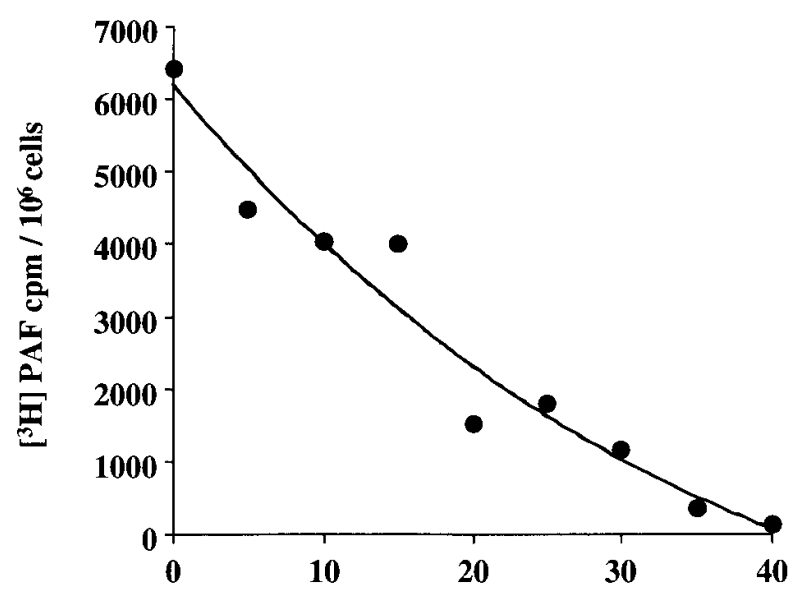

Time (min) That Antibody Was Present
Figure 3. The alpha toxin effects on endothelial cells require active toxin. (A) Endothelial cell monolayers were incubated for a total of $40 \mathrm{~min}$ with $\mathrm{HBSS} / \mathrm{A} / \mathrm{Zn}^{2+}$ containing $\left[{ }^{3} \mathrm{H}\right]$ acetate in the presence or absence of $0.2 \mathrm{U} / \mathrm{ml}$ alpha toxin and/or a neutralizing antibody to alpha toxin. $(B)$ $0.2 \mathrm{U} / \mathrm{ml}$ alpha toxin was added to endothelial cells in the presence of $\mathrm{HBSS} / \mathrm{A} / \mathrm{Zn}^{2+}$ and $\left[{ }^{3} \mathrm{H}\right]$ acetate. At varying times after the addition of alpha toxin, a neutralizing $\mathrm{mAb}$ to alpha toxin was added. All monolayers were incubated with the alpha toxin for a total of $40 \mathrm{~min} .\left[{ }^{3} \mathrm{H}\right] \mathrm{PAF}$ was measured as in Fig. 1. Each graph depicts the results of single experiments but are representative of a total of four experiments which were conducted similarly. 


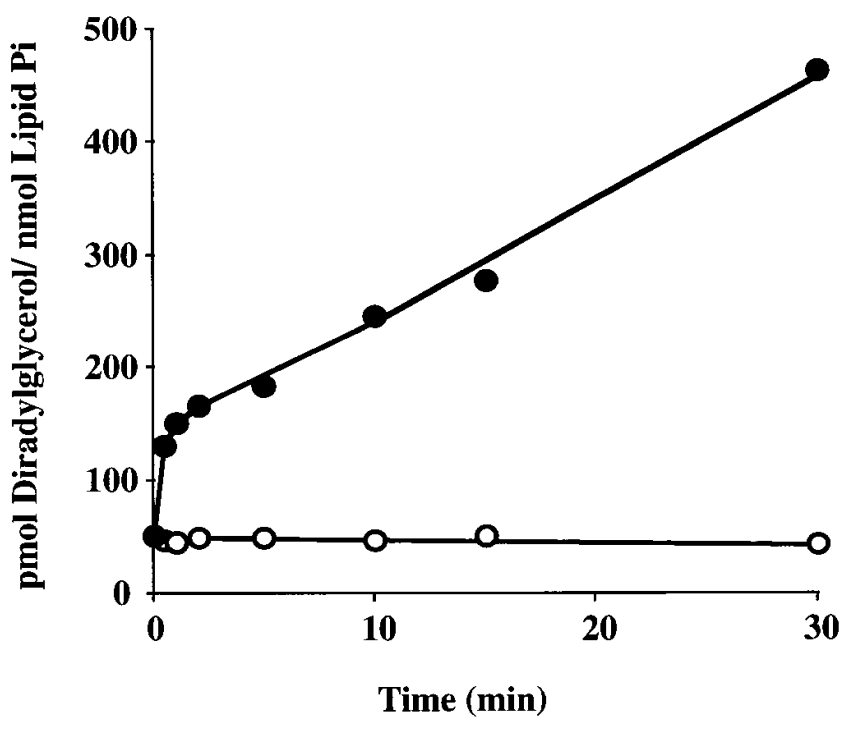

Figure 4. Clostridial alpha toxin catalyzes the accumulation of diradylglycerol in endothelial cells. Human endothelial cells were incubated with $0.2 \mathrm{U} / \mathrm{ml}$ alpha toxin (filled circles) or $\mathrm{HBSS} / \mathrm{A} / \mathrm{Zn}^{2+}$ buffer only (open circles) for the times shown. Cellular lipids were extracted and incubated with DAG kinase in the presence of [ $\left.{ }^{32} \mathrm{P}\right] \mathrm{ATP}$. $\left[{ }^{32} \mathrm{P}\right] \mathrm{Phosphatidic}$ acid was isolated by TLC and estimated by scintillation spectrometry. The amount of diradylglycerol in each sample was then calculated from standard curves. The results shown are from a single experiment but are representative of two similarly conducted experiments. In another experiment we measured a similar accumulation of radiolabeled diradylglycerol in response to alpha toxin in endothelial cells that had been prelabeled with $\left[{ }^{3} \mathrm{H}\right]$ arachidonate.

ished (data not shown). In contrast, when the toxin was incubated with the endothelial cells for increasing periods of time before neutralization with the specific antibody, we observed intermediate stimulation of PAF. This result strongly suggests that the action of the toxin was due to the hydrolysis of membrane phospholipids, rather than a traditional signal transduction event after binding to a receptor.

To directly examine the phospholipase $\mathrm{C}$ activity of alpha toxin on endothelial cells we measured the amounts of diradylglycerol formed at various times after exposure to the toxin. We found a time-dependent increase of both, as shown in Fig. 4. We further analyzed the diradylglycerol pool and found that $11.5 \pm 6.8 \%$ was comprised of 1-alkyl, 2-acylglycerol with the remainder being DAG. In the same experiment we observed that ceramide levels also increased in response to alpha toxin treatment. Additional studies in which phospholipids were labeled with $\left[{ }^{3} \mathrm{H}\right]$ choline or $\left[{ }^{32} \mathrm{P}\right]$ phosphate demonstrated a time-dependent loss of cellular sphingomyelin and phosphatidylcholine in response to alpha toxin treatment (data not shown).

We previously demonstrated that the initial step of PAF synthesis in response to receptor-mediated agonists, the activation of an arachidonate-specific phospholipase $A_{2}$, requires activation of PKC (32). The accumulation of DAG, an endogenous activator of $\mathrm{PKC}$, in alpha toxin-stimulated endothelial cells suggested that this mechanism is also involved in PAF synthesis. To test this possibility we exposed endothelial cells to the toxin in the presence or absence of PKC inhibitors as shown in Fig. 5. Staurosporine and sphingosine both inhibited the synthesis of PAF in a concentration-dependent fashion. In an additional experiment we saw partial inhibition with sangivamycin at concentrations of $1 \mu \mathrm{M}$ and $10 \mu \mathrm{M}$. These results suggest alpha toxin elicits proinflammatory responses by endothelial cells, in part through the elevation of intracellular DAG, mediated by intrinsic phospholipase $\mathrm{C}$ activity, and subsequent activation of PKC.

PMNs adhere to alpha toxin-stimulated endothelial cells. We have shown that the cell-associated PAF signals PMNs when it is expressed by endothelial cells stimulated with thrombin and histamine, resulting in activation-dependent functional upregulation of $\beta_{2}$ integrins and adhesion of the leukocytes to the endothelial surface $(15,17)$. The endothelial
A

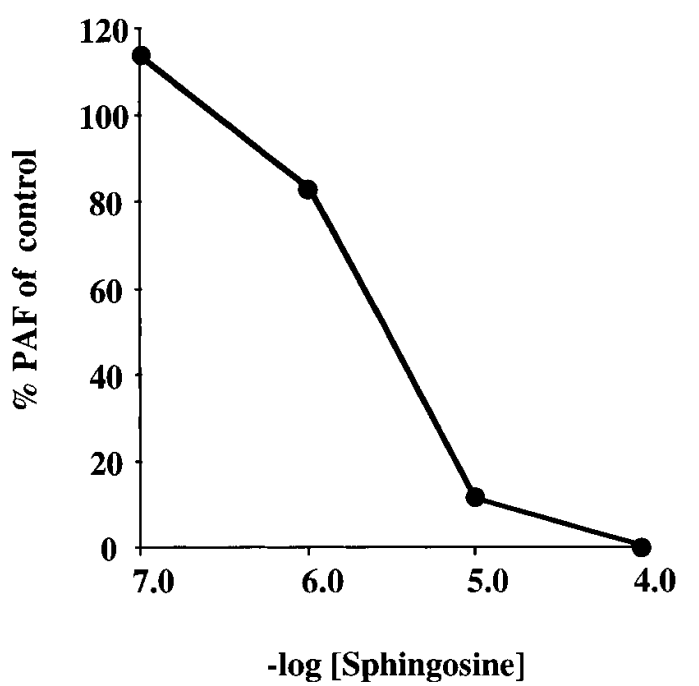

B

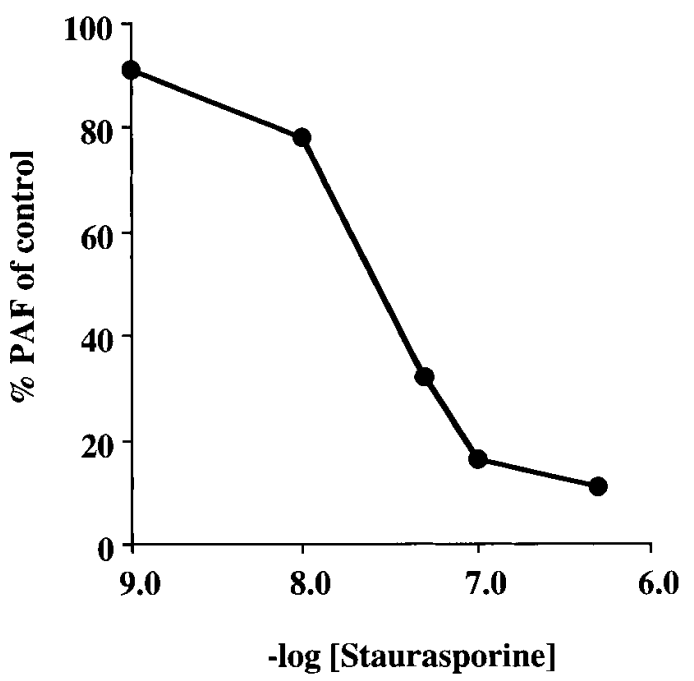

Figure 5. PAF synthesis by alpha toxin-stimulated endothelial cells requires the activation of PKC. Human endothelial cells were preincubated in $\mathrm{HBSS} / \mathrm{A} / \mathrm{Zn}^{2+}$ containing various concentrations of $(A)$ sphingosine $(100 \mathrm{nM}$ to 100 $\mu \mathrm{M})$ or $(B)$ staurosporine $(1 \mathrm{nM}$ to $500 \mathrm{nM})$ for 15 min, respectively, and then were stimulated with $0.2 \mathrm{U} / \mathrm{ml}$ alpha toxin for $40 \mathrm{~min} .\left[{ }^{3} \mathrm{H}\right] \mathrm{PAF}$ was measured as in Fig. 1. Each graph depicts the results of single experiments but are representative of four experiments which were conducted similarly. 
A

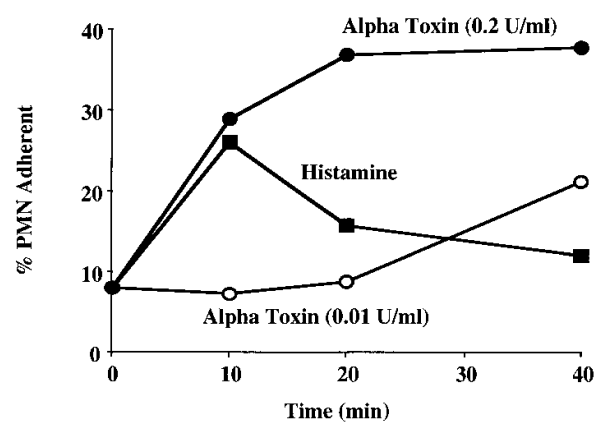

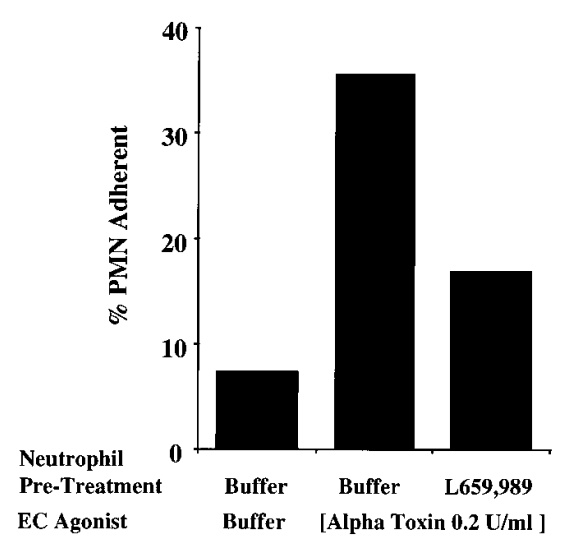

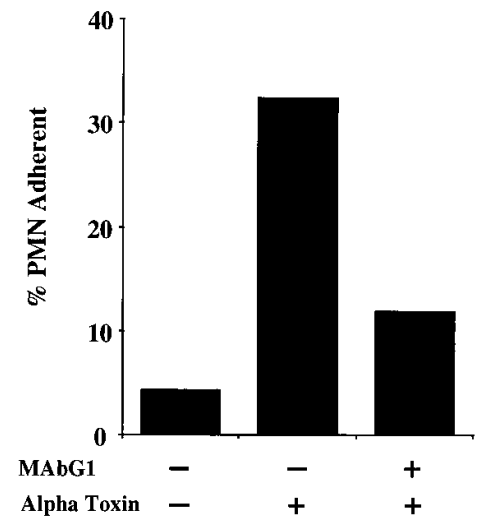

Figure 6. PMNs adhere to alpha toxin-treated endothelial cells through a PAF and P-selectin-mediated process. $(A)$ Endothelial cells were pretreated with HBSS/A containing $0.01 \mathrm{U} / \mathrm{ml}$ alpha toxin (open circles), $0.2 \mathrm{U} / \mathrm{ml}$ alpha toxin (filled circles), or $10^{-4} \mathrm{M}$ histamine (filled squares) for the times shown. After incubation the monolayers were washed with HBSS/A and overlaid with ${ }^{111}$ In-labeled PMNs for 5 min. The excess PMNs were removed and the adherent ${ }^{111}$ In PMNs were quantified by gamma counting. (B) Endothelial cells were pretreated for 40 min with HBSS/A containing $0.2 \mathrm{U} / \mathrm{ml}$ alpha toxin or HBSS/A alone. After pretreatment the monolayers were washed and overlaid with ${ }^{111} \mathrm{In}$-labeled PMNs in HBSS/A or HBSS/A containing $100 \mu \mathrm{M}$ L659,989, a PAF receptor antagonist. The excess PMNs were removed and adherent ${ }^{111}$ In-labeled PMNs were quantified as above. $(C)$ Endothelial cells were stimulated for $60 \mathrm{~min}$ with $0.2 \mathrm{U} / \mathrm{ml}$ alpha toxin. An antibody which inhibits P-selectin-mediated adhesion, $\mathrm{mAb} \mathrm{G1}$, was included in the latter $30 \mathrm{~min}$ of the alpha toxin stimulation at $25 \mu \mathrm{g} / \mathrm{ml}$ and the corresponding neutrophils were preincubated for $10 \mathrm{~min}$ with $10 \mu \mathrm{g} / \mathrm{ml} \mathrm{mAb} \mathrm{G1} \mathrm{before} \mathrm{the} \mathrm{adhesion} \mathrm{assay.}$

cell-dependent mechanism of PMN adhesion resulting from juxtacrine signaling by PAF may be critical in leukocyte targeting under some conditions in vivo (for review see reference 33). However, it may also be involved in pathologic leukocyte accumulation. Endothelial cells which had been exposed to alpha toxin were also found to be adhesive for PMNs. As shown in Fig. $6 \mathrm{~A}$, adherence was dependent on the time of preincubation and the concentration of alpha toxin. The alpha toxintreated endothelial cells were adhesive for PMNs for prolonged periods in contrast to endothelial cells activated by histamine in parallel. We tested whether toxin-induced adherence was mediated via the PAF which was synthesized by the endothelial cells under these conditions (Fig. 1). This was accomplished by pretreating the neutrophils with a selective antagonist of the PAF receptor $(15,17)$, L659,989, before placing them on the EC monolayers. As shown in Fig. 6 , pretreatment with L659,989 diminished the binding of PMNs to the endothelial cell monolayer. In control experiments (not shown), L659,989 inhibited PMN adhesion to resting unstimulated endothelial cells induced by exogenously added PAF $\left(10^{-7} \mathrm{M}\right)$ but did not inhibit PMN adhesion induced by $N$-formylmethionyl-leucyl-phenylalanine $\left(10^{-7} \mathrm{M}\right)$, which is recognized by a different receptor.

Although the alpha toxin was washed from the endothelial cell monolayers before the addition of neutrophils in these studies, we examined whether alpha toxin could elicit neutrophil adhesion in the absence of endothelial cells. When we incubated neutrophils on gelatin-coated dishes for $10 \mathrm{~min}$ in the presence of 0.02 or $0.2 \mathrm{U}$ of alpha toxin neutrophil adhesion was not observed, indicating that the adhesion of neutrophils to endothelial cells in these experiments requires the activation of the endothelial cells.

We have previously demonstrated that stimulated endothe- lial cells express P-selectin on the plasma membrane concomitant with PAF synthesis and that maximal adhesion of PMNs to endothelial cells stimulated by histamine and thrombin requires the cooperative action of P-selectin and PAF (15). To examine whether P-selectin also contributed to the alpha toxin-elicited neutrophil adhesion we examined the effects of a specific antibody to P-selectin, $\mathrm{mAb}$ G1, which, when bound to endothelial cell surfaces, prevents P-selectin-mediated PMN adhesion $(14,15)$. As shown in Fig. $6 C$ we observed that mAb G1 significantly inhibited PMN adhesion to alpha toxinstimulated endothelial cells. In two independent experiments, endothelial cells were pretreated with $0.2 \mathrm{U} / \mathrm{ml}$ alpha toxin for either 30 or $60 \mathrm{~min}$; the $\mathrm{mAb} \mathrm{G} 1$ and a PAF receptor antagonist (10 $\mu \mathrm{M}$ WEB 2086) were both included in the assay; and we found that the PMN adhesion was abolished. These findings indicate that cooperative tethering of PMNs by P-selectin and signaling by PAF (Fig. $6 B$ ) are involved when PMNs adhere to endothelial cells treated with alpha toxin (Fig. $6 A$ ). In an experiment not shown, an antibody against the PMN $\beta_{2}$ integrins partially inhibited PMN adhesion to alpha toxin-activated endothelial monolayers. This is consistent with our previous observation that activation of PMNs by PAF expression by endothelial cells induces functional upregulation of the integrins on the leukocyte surface, amplifying adhesion. Because tethering of PMNs by P-selectin and signaling by PAF also primes them for enhanced granular enzyme release (16), this may contribute to local vascular injury when alpha toxin induces prolonged accumulation of the leukocytes (Fig. 6A).

Alpha toxin stimulates P-selectin expression in endothelial cells and neutrophil accumulation in tissue in vivo. To further examine the role of alpha toxin in mediating neutrophil adhesion and subsequent extravasation we injected Sprague-Dawley rats intramuscularly with either PBS or PBS containing $1 \mathrm{U}$ 

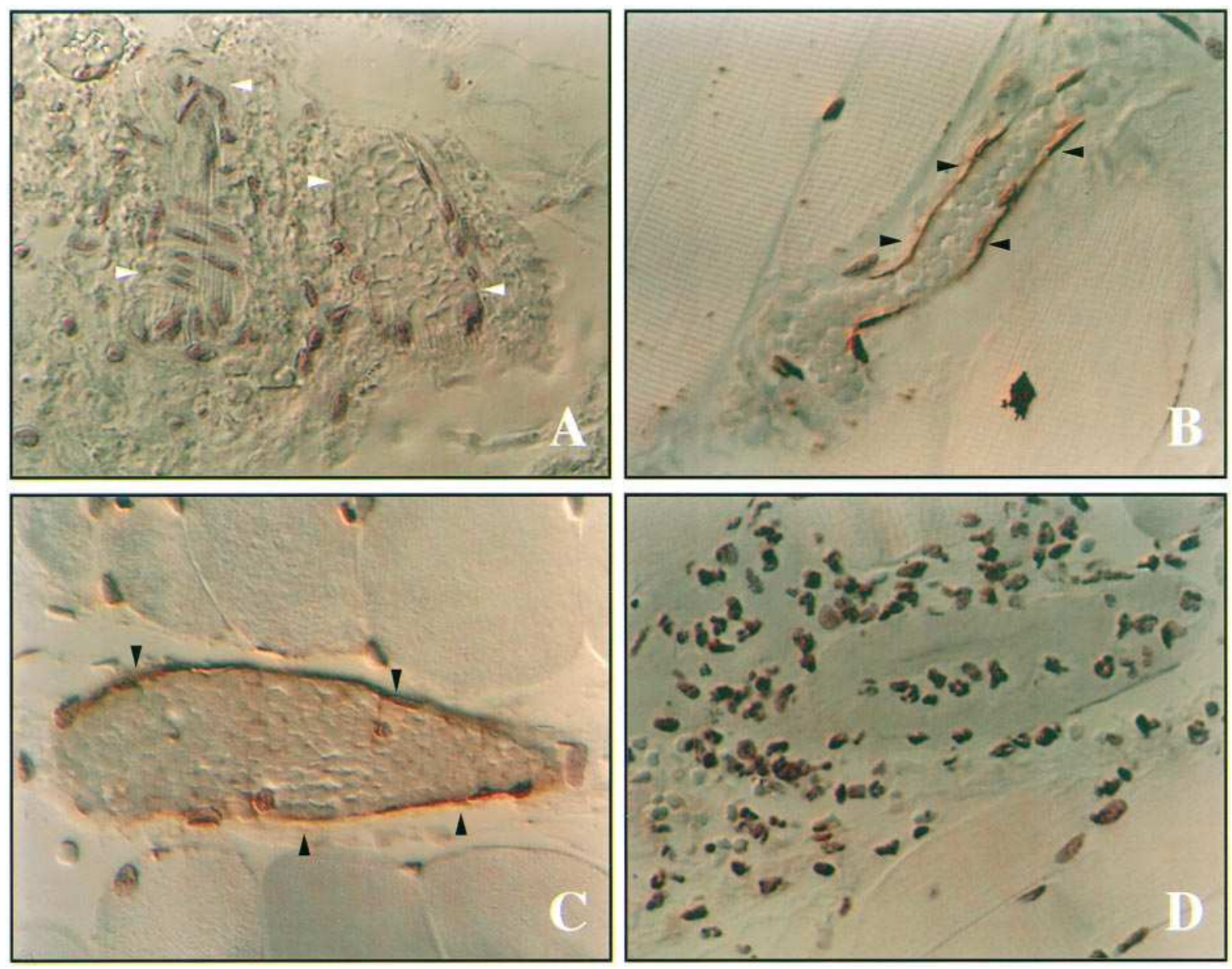

Figure 7. P-selectin expression and neutrophil accumulation in response to alpha toxin in vivo. Sprague-Dawley rats were injected with either PBS $(A)$ or PBS containing alpha toxin $(B-D)$ and tissue sections were taken from the site of injection and stained for P-selectin expression with the monoclonal antibody PB $1(A-C)$. All sections were counterstained with hematoxylin. $(A)$ Rat tissue taken $1 \mathrm{~h}$ after the injection of PBS showing an absence of P-selectin expression at the vascular wall shown by white arrows. $(B, C)$ Rat tissue taken $20 \mathrm{~min}(B)$ and $1 \mathrm{~h}(C)$ after the injection of alpha toxin showing the presence of P-selectin expression by endothelial cells shown by black arrows. $(D)$ Rat tissue taken $4 \mathrm{~h}$ after the injection of alpha toxin showing the accumulation of extravascular neutrophils.

of alpha toxin. P-selectin expression was detected by immunohistochemistry on the surface of endothelial cells in tissue sections taken at $20 \mathrm{~min}$ and $1 \mathrm{~h}$ after the injection (Fig. 7, $B$ and $C$ ), and neutrophil accumulation in the extravascular space was apparent at 2 and $4 \mathrm{~h}($ Fig. $7 \mathrm{D})$. P-selectin expression and neutrophil accumulation were absent in PBS-injected controls which were analyzed 1 and $4 \mathrm{~h}$ after injection (Fig. $7 A$ ).

\section{Discussion}

Clostridium perfringens alpha toxin, a phospholipase C, plays a significant role in the development of gas gangrene. Both alpha antitoxin and an alpha toxoid vaccine protect against $C$. perfringens type A infections $(3,4)$, and alpha toxin-deficient bacterial strains exhibit reduced virulence (5). Additional studies have further associated some of the clinical manifestations of gas gangrene infections with alpha toxin. When partially purified exotoxin filtrates containing alpha toxin were injected into muscle tissue, significant myonecrosis resulted (2). Upon closer inspection, accumulation of neutrophils in vessels at the border of the necrotic tissue was found, in addition to evidence of increased vascular permeability. Furthermore, rabbits which received an intravenous injection of purified alpha toxin exhibited decreased cardiac output, bradycardia, hypotension, and subsequently died (34). Thus alpha toxin is a critical determinant of local and systemic vascular manifestations of clostridial infections. It is likely that the alpha toxin also contributes to endothelial injury and dysregulated accumulation of PMNs in lung injury associated with $C$. perfringens septicemia (35).

Although the phospholipase $\mathrm{C}$ activity of alpha toxin is not detectable in the venous blood of infected animals (36), endothelial cells may be exposed to alpha toxin in localized areas of vascular damage. Enzymatic hydrolysis of endothelial membranes by alpha toxin may then induce some of the clinical manifestations of gas gangrene and other clostridial infections. We demonstrated that cultured human endothelial cells treated with recombinant alpha toxin synthesize two potent vasoactive compounds, PAF and prostacyclin, and become adhesive for neutrophils. We also observed that rat endothelial 
cells express P-selectin and elicit neutrophil extravasation and accumulation in response to alpha toxin in vivo. These endothelial cell responses are important for vascular homeostasis but when activated in a dysregulated manner by $C$. perfringens alpha toxin may contribute to both localized and systemic effects after infection.

PAF is a potent lipid mediator which has been demonstrated to activate inflammatory cells (37-39) and increase vascular permeability $(40,41)$, and may contribute to myocardial dysfunction in a variety of pathogenic settings (42-44). We found that alpha toxin induces HUVEC to synthesize PAF by a process that depends on the concentration of the toxin in the overlaying medium and the length of time the monolayers are incubated with the toxin. We demonstrated that this endothelial cell response was blocked by an alpha toxin antibody which confirmed that the effect was not the result of a contaminant in the toxin preparation. Furthermore, when we added the antibody, which blocks the enzymatic activity, at varying times after the addition of the alpha toxin, the amount of PAF accumulation was found to be proportional to the time of exposure to active toxin (Fig. 3). This result supports our conclusion that the toxin stimulated the cells by virtue of its intrinsic enzymatic activity as a phospholipase $\mathrm{C}$. We observed the accumulation of the phospholipase $\mathrm{C}$ reaction products, 1,2 diradylglycerol and ceramide, as well as a loss of the phospholipid substrates, phosphatidylcholine and sphingomyelin, in toxin-stimulated cells. We demonstrated previously that PAF synthesis by stimulated endothelial cells requires PKC activation (32), and have shown that alpha toxin induces PAF synthesis by a pathway that requires the enzymatic activity of the toxin and is inhibited by agents that block PKC activation. Although the PKC inhibitors used in this study are known to diminish PKC activity, we cannot rule out the possibility that these compounds may also inhibit other cellular kinases which are required for PAF synthesis. Direct activation of PKC by alpha toxin may be mediated through the enzymatic production of DAG, an endogenous activator of most PKC isoforms. Furthermore, the liberated diradylglycerol may participate in other responses of endothelial cells activated by alpha toxin as may ceramide, which can activate some components of the MAP kinase pathway in endothelial monolayers (45). Thus together with theta toxin from $C$. perfringens $(20,21,32,34)$ the alpha toxin can induce a number of signaling pathways in endothelium during infections by these organisms.

PAF synthesis by endothelial cells may contribute to localized inflammatory events observed in gas gangrene infections including enhanced vascular permeability and neutrophil recruitment. Increased vascular permeability has been observed previously in response to highly purified alpha toxin (46) and may significantly contribute to the marked edema observed in gangrenous tissues. We demonstrated that endothelial cells stimulated with alpha toxin also became adherent for neutrophils and that adherence was mediated by PAF and P-selectin. Furthermore, we also observed P-selectin expression by rat endothelial cells and neutrophil accumulation in muscle tissue after alpha toxin injection. The expression of P-selectin on the surface of the endothelial cells was rapid and is most likely a consequence of the release of Weibal-Palade bodies, as others have demonstrated that changes in P-selectin transcription are only observed after longer incubation periods (47). Unlike the response to physiological agonists, which leads to a transient expression of an adhesive surface (17), alpha toxin-stimulated endothelial cells remained adhesive to PMNs for a prolonged period of time (Fig. $6 \mathrm{~A}$ ). This may contribute to sequestration of leukocytes in vessels at the perimeter of necrotic muscle in gas gangrene (2). The unique paucity of PMNs within the primary necrotic zones of $C$. perfringens-infected tissue may also reflect the lysis of neutrophils by the leukocytolytic activity of theta toxin (20) as histological examination of necrotic muscle tissue has shown that PMNs at the border of infection appeared karyolytic (2).

PAF accumulation in response to alpha toxin by endothelial cells was different from other agonists which we have studied in several ways. First, the time of maximal $\left[{ }^{3} \mathrm{H}\right] \mathrm{PAF}$ accumulation depended on the quantity of active toxin in the medium. That is to say, the endothelial cells demonstrated maximal PAF accumulation in response to a high concentration of alpha toxin $(0.6 \mathrm{U} / \mathrm{ml})$ at $\sim 20 \mathrm{~min}$. However, PAF levels continued to increase as late as $1 \mathrm{~h}$ after the addition of a lower concentration of toxin $(0.05 \mathrm{U} / \mathrm{ml})$. Second, the delayed and prolonged accumulation of PAF in response to alpha toxin was unlike the tightly regulated and transient expression of PAF in response to physiological agonists such as histamine, bradykinin, thrombin, and ATP (Fig. $6 A$ and reference 23). Finally, a portion of the $\left[{ }^{3} \mathrm{H}\right] \mathrm{PAF}$ synthesized by the monolayer was released into the overlying medium. This is the first example we have seen in which PAF is released from the endothelial cells, and may reflect membrane disruption by the action of alpha toxin. During gas gangrene infections, release of even small quantities of PAF could disrupt vascular homeostasis through the activation of a variety of inflammatory cells beyond the site of infection, including platelets (37), neutrophils (38), and macrophages (39).

In addition to PAF, alpha toxin-stimulated endothelial cells synthesized and secreted prostacyclin, another potent vasoactive lipid. Prostacyclin, an arachidonate metabolite, is both a vasodilator (30) and an antithrombotic agent (48). The coordinated synthesis of prostacyclin and PAF synthesis by HUVEC has been demonstrated previously (23) and most likely reflects the cleavage of phosphatidylcholine by a $\mathrm{PLA}_{2}$ activity leading to the production of arachidonic acid and the PAF biosynthetic precursor, lysoPAF $(49,50)$. The activation of $\mathrm{PLA}_{2}$ in these studies may be mediated in part through $\mathrm{PKC}$, as this kinase has been shown previously to regulate $\mathrm{PLA}_{2}$ activity. We observed that endothelial cells labeled with arachidonic acid released a labeled species into the supernatant after alpha toxin treatment. From RIA we demonstrated that the toxin stimulated HUVEC secreted 6-ketoPGF ${ }_{1 \alpha}$, a stable degradation product of prostacyclin. Although prostacyclin and PAF can elicit contrasting responses from the vasculature, the local concentration of each may markedly differ especially as the majority of the PAF is retained by the endothelial cells and prostacyclin is primarily released into the fluid phase.

In summary, we describe new biological properties of the C. perfringens alpha toxin. Our studies suggest that some of the localized and systemic effects of gas gangrene infections may be modulated by the primary responses of endothelial cells to alpha toxin. Furthermore, prolonged exposure of endothelial cells to alpha toxin was also recently shown to induce surface expression of intercellular leukocyte adherence molecule-1 and E-selectin (endothelial cell-leukocyte adherence molecule-1) as well as synthesis of interleukin-8 (21). The expression of these molecules after prolonged exposure to alpha toxin may also add to the accumulation and inappropriate acti- 
vation of PMNs at the periphery of the necrotic regions of infection. These studies further demonstrate that the endothelium is a critical target for bacterial toxins other than gramnegative lipopolysaccharide, a classic agonist for this cell type (51). Additional study of the primary and secondary effects of $C$. perfringens exotoxins in the regulation of other inflammatory mediators may also aid in the understanding of many clinical manifestations of gas gangrene infections which eventually result in profound shock and death.

\section{Acknowledgments}

The authors thank Eric Stroud, Donnelle Benson, David Carlton, Holly Nichols, Wenhua Li, and Margaret Vogel for their excellent technical assistance. We greatly appreciate the help of the nurses and staff of the labor and delivery service of LDS Hospital in collecting umbilical samples. We also thank John Fenton for the purified thrombin, Diana Stafforini for the purified PAF acetylhydrolase, and J.Y. Tso for the purified recombinant alpha toxin and the corresponding neutralizing antibody, and Kevin Moore and Rod McEver for the monoclonal antibody G1.

This work was supported by the National Institutes of Health grants HL-34127, HL-44525, and HL-50153, a Physician Scientist Award (HL-02726) to D.E. Lorant, and the Nora Eccles Treadwell Foundation.

\section{References}

1. MacLennan, J.D. 1962. The histotoxic clostridial infections of man. Bacteriol. Rev. 26:177-276.

2. Robb-Smith, A.H.T. 1945. Tissue changes induced by $\mathrm{Cl}$. welchii type A filtrates. Lancet. 362-368.

3. Kameyama, S., H. Sato, and R. Murata. 1972. The role of $\alpha$-toxin of Clostridium perfringens in experimental gas gangrene in guinea pigs. Jpn. J. Med. Sci. Biol. 25:200.

4. Williamson, E.D., and R.W. Titball. 1993. A genetically engineered vaccine against the alpha-toxin of Clostridium perfringens protects mice against experimental gas gangrene. Vaccine. 11:1253-1258.

5. Awad, M.M., A.E. Bryant, D.L. Stevens, and J.I. Rood. 1995. Virulence studies on chromosomal $\alpha$-toxin and $\theta$-toxin mutants constructed by allelic exchange provide genetic evidence for the essential role of $\alpha$-toxin in Clostridium perfringens-mediated gas gangrene. Mol. Microbiol. 15:191-202.

6. Macfarlane, M. G. 1948. The biochemistry of bacterial toxins. Biochem J. 42:587-590.

7. Macfarlane, M.G., and B.C.J.G. Knight. 1941. The biochemistry of bacterial toxins. Biochem. J. 35:884-902.

8. Tso, J.Y., and C. Siebel. 1989. Cloning and expression of the phospholipase $\mathrm{C}$ gene from Clostridium perfringens and Clostridium bifermentans. Infect. Immun. 57:468-476.

9. Titball, R.W., S.E.C. Hunter, K.L. Martin, B.C. Morris, A.D. Shuttleworth, T. Rubidge, D.W. Anderson, and D.C. Kelly. 1989. Molecular cloning and nucleotide sequence of the alpha-toxin (phospholipase C) of Clostridium perfringens. Infect. Immun. 57:367-376.

10. Leslie, D., N. Fairweather, D. Pickard, G. Dougan, and M. Kehoe. 1989. Phospholipase $\mathrm{C}$ and haemolytic activities of Clostridium perfringens alphatoxin cloned in Escherichia coli: sequence and homology with a Bacillus cereus phospholipase C. Mol. Microbiol. 3:383-392.

11. Okabe, A., T. Shimizu, and H. Hayashi. 1989. Cloning and sequencing of a phospholipase C gene of Clostridium perfringens. Biochem. Biophys. Res. Commun. 160:33-39.

12. Zimmerman, G.A., T.M. McIntyre, and S.M. Prescott. 1985. Thrombin stimulates the adherence of neutrophils to human endothelial cells in vitro. $J$. Clin. Invest. 76:2235-2246.

13. McIntyre, T.M., G.A. Zimmerman, and S.M. Prescott. 1986. Leukotrienes $\mathrm{C}_{4}$ and $\mathrm{D}_{4}$ stimulate human endothelial cells to synthesize platelet-activating factor and bind neutrophils. Proc. Natl. Acad. Sci. USA. 83:2204-2208.

14. Geng, J.G., M.P. Bevilacqua, K.L. Moore, T.M. McIntyre, S.M. Prescott, J.M. Kim, G.A. Bliss, G.A. Zimmerman, and R.P. McEver. 1990. Rapid neutrophil adhesion to activated endothelium mediated by GMP-140. Nature (Lond.). 343:757-760.

15. Lorant, D.E., K.D. Patel, T.M. McIntyre, R.P. McEver, S.M. Prescott, and G.A. Zimmerman. 1991. Coexpression of GMP-140 and PAF by endothelium stimulated by histamine or thrombin. A juxtacrine system for adhesion and activation of neutrophils. J. Cell Biol. 115:223-234.
16. Lorant, D.E., M.K. Topham, R.E. Whatley, R.P. McEver, T.M. McIntyre, S.M. Prescott, and G.A. Zimmerman. 1993. Inflammatory roles of P-selectin. J. Clin. Invest. 92:559-570.

17. Zimmerman, G.A., T.M. McIntyre, M. Mehra, and S.M. Prescott. 1990. Endothelial cell-associated platelet-activating factor. A novel mechanism for signaling intercellular adhesion. J. Cell Biol. 110:529-540.

18. Stafforini, D.M., S.M. Prescott, and T.M. McIntyre. 1987. Human plasma platelet-activating factor acetylhydrolase: purification and properties. $J$. Biol. Chem. 262:4223-4230.

19. Sato, H., J. Chiba, and Y. Sato. 1989. Monoclonal antibodies against alpha-toxin of Clostridium perfringens. FEMS (Fed. Eur. Microbiol. Soc.) Microbiol. Lett. 59:173-176.

20. Stevens, D.L., J. Mitten, and C. Henry. 1987. Effects of $\alpha$ and $\theta$ toxins from Clostridium perfringens on human polymorphonuclear leukocytes. J. Infect. Dis. 156:324-333.

21. Bryant, A.E., and D.L. Stevens. 1996. Phospholipase C and perfringolysin $\mathrm{O}$ from Clostridium perfringens upregulate endothelial cell-leukocyte adherence molecule 1 and intercellular leukocyte adherence molecule 1 expression and induce interleukin-8 synthesis in cultured human umbilical vein endothelial cells. Infect. Immun. 64:358-362.

22. Zimmerman, G.A., R.E. Whatley, T.M. McIntyre, D.M. Benson, and S.M. Prescott. 1990. Endothelial cells for studies of platelet-activating factor and arachidonate metabolites. Methods Enzymol. 187:520-535.

23. McIntyre, T.M., G.A. Zimmerman, K. Satoh, and S.M. Prescott. 1985. Cultured endothelial cells synthesize both platelet-activating factor and prostacyclin in response to histamine, bradykinin, and adenosine triphosphate. J. Clin. Invest. 76:271-280.

24. Bligh, E.G., and W.J. Dyer. 1959. A rapid method of total lipid extraction and purification. Can. J. Biochem. Physiol. 37:911-917.

25. Preiss, J., C.R. Loomis, W.R. Bishop, R. Stein, J.E. Niedel, and R.M. Bell. 1986. Quantitative measurement of $s n$-1,2-diacylglycerols present in platelets, hepatocytes, and ras- and sis-transformed normal rat kidney cells. J. Biol. Chem. 261:8597-8600.

26. Mulligan, M.S., M.J. Polley, R.J. Bayer, M.F. Nunn, J.C. Paulson, and P.A. Ward. 1992. Neutrophil-dependent acute lung injury. J. Clin. Invest. 90: 1600-1607.

27. Patel, K.D., G.A. Zimmerman, S.M. Prescott, and T.M. McIntyre. 1992. Novel leukocyte agonists are released by endothelial cells exposed to peroxide. J. Biol. Chem. 267:15168-15175.

28. Mueller, H.W., J.T. O'Flaherty, and R.L. Wykle. 1983. Biosynthesis of platelet-activating factor in rabbit polymorphonuclear neutrophils. J. Biol. Chem. 258:6213-6218.

29. Prescott, S.M., G.A. Zimmerman, and T.M. McIntyre. 1984. Human endothelial cells in culture produce platelet-activating factor (1-alkyl-2-acetyl-snglycero-3-phosphocholine) when stimulated with thrombin. Proc. Natl. Acad. Sci. USA. 81:3534-3538.

30. Johnson, R.A., D.R. Morton, J.H. Kinner, R.R. Gorman, J.C. McGuire, and F.F. Sun. 1976. The chemical structure of prostaglandin X (prostacyclin). Prostaglandins. 12:915-928.

31. Whatley, R.E., G.A. Zimmerman, T.M. McIntyre, and S.M. Prescott. 1990. Lipid metabolism and signal transduction in endothelial cells. Prog. Lipid Res. 29:45-63.

32. Whatley, R.E., P. Nelson, G.A. Zimmerman, D.L. Stevens, C.J. Parker, T.M. McIntyre, and S.M. Prescott. 1989. The regulation of platelet-activating factor production in endothelial cells. J. Biol. Chem. 264:6325-6333.

33. Lorant, D.E., G.A. Zimmerman, T.M. McIntyre, and S.M. Prescott. 1995. Platelet-activating factor mediates procoagulant activity on the surface of endothelial cells by promoting leukocyte adhesion. Semin. Cell Biol. 6:295-303.

34. Stevens, D.L., B.E. Troyer, D.T. Merrick, J.E. Mitten, and R.D. Olson. 1988. Lethal effects and cardiovascular effects of purified $\alpha$ - and $\theta$-toxins from Clostridium perfringens. J. Infect. Dis. 157:272-279.

35. Dalldorf, F.G., C.N. Carney, C.E. Rackley, and R.B. Raney. 1968. Pulmonary capillary thrombosis in septicemia due to gram-positive bacteria. JAMA (J. Am. Med. Assoc.). 206:583-586.

36. Macfarlane, R.G., and J.D. MacLennan. 1945. The toxemia of gas-gangrene. Lancet. 328-331.

37. Benveniste, J., J.P. Le Couedic, and P. Kamoun. 1975. Letter: Aggregation of human platelets by platelet-activating factor. Lancet. 344-345.

38. O'Flaherty, J.T., R.L. Wykle, C.H. Miller, J.C. Lewis, M. Waite, D.A. Bass, C.E. McCall, and L.R. DeChatelet. 1981. 1-O-Alkyl-sn-glyceryl-3-phosphorylcholines. Am. J. Pathol. 103:70-79.

39. Hayashi, H., I. Kudo, K. Inoue, H. Nomura, and S. Nojima. 1985. Macrophage activation by PAF incorporated into dipalmitoylphosphatidylcholinecholesterol liposomes. J. Biochem. 97:1255-1258.

40. Bjork, J., L. Lindbom, B. Gerdin, G. Smedegard, K.E. Arfors, and J. Benveniste. 1983. Paf-acether (platelet-activating factor) increases microvascular permeability and affects endothelium-granulocyte interaction in microvascular beds. Acta. Physiol. Scand. 119:305-308.

41. Humphrey, D.M., L.M. McManus, D.J. Hanahan, and R.N. Pinckard. 1984. Morphologic basis of increased vascular permeability induced by acetyl glyceryl ether phosphorylcholine. Lab. Invest. 50:16-25.

42. Holland, M.R., T.M. McIntyre, G.A. Zimmerman, and S.M. Prescott. 
1991. Cardiovascular effects of platelet-activating factor. Trends. Cardiovasc. Med. 1:117-121.

43. Levi, R., J.A. Burke, Z.G. Guo, Y. Hattori, C.M. Hoppens, L.M. McManus, D.J. Hanahan, and R.N. Pinckard. 1984. Acetyl glyceryl ether phosphorylcholine (AGEPC). Circ. Res. 54:117-124.

44. McManus, L.M., D.S. Woodard, S.I. Deavers, and R.N. Pinckard. 1993. Biology of disease. Lab. Invest. 69:639-650.

45. Modur, V., G.A. Zimmerman, S.M. Prescott, and T.M. McIntyre. 1996. Endothelial cell inflammatory responses to tumor necrosis factor alpha. Ceramide-dependent and -independent mitogen-activated protein kinase cascades. J. Biol. Chem. 271:13094-13102.

46. Sugahara, T., T. Takahashi, S. Yamaya, and A. Ohsaka. 1977. Vascular permeability increase by $\alpha$-toxin (phospholipase C) of Clostridium perfringens. Toxicon. 15:81-87.

47. Yao, B.L., J. Pan, H. Setiadi, K.D. Patel, and R.P. McEver. 1996. Inter- leukin 4 or oncostatin $\mathrm{M}$ induces a prolonged increase in P-selectin mRNA and protein in human endothelial cells. J. Exp. Med. 184:81-92.

48. Moncada, S., R. Gryglewski, S. Bunting, and J.R. Vane. 1976. An enzyme isolated from arteries transforms prostaglandin endoperoxides to an unstable substance that inhibits platelet aggregation. Nature (Lond.). 263:663-665

49. Chilton, F.H., J.M. Ellis, S.C. Olson, and R.L. Wykle. 1984. 1-O-Alkyl2-arachidonoyl-sn-glycero-3-phosphocholine: a common source of platelet-activating factor and arachidonate in human polymorphonuclear leukocytes. $J$. Biol. Chem. 259:12014-12019.

50. Ramesha, C.S., and W.C. Pickett. 1986. Platelet-activating factor and leukotriene biosynthesis is inhibited in polymorphonuclear leukocytes depleted of arachidonic acid. J. Biol. Chem. 261:7592-7595.

51. Gill, E.A., T.M. McIntyre, S.M. Prescott, and G.A. Zimmerman. 1992. Mechanisms of vascular injury in the pathogenesis of infectious disease. Curr. Opin. Infect. Dis. 5:381-388. 